\title{
The Securitization of Fear in Post-Tsunami Sri Lanka
}

\author{
Jennifer Hyndman \\ Department of Geography, Maxwell School, Syracuse University
}

\begin{abstract}
Fear is a potent political resource that is at once an expression of vulnerability to geopolitical threats and a rationale for security measures against them. It is produced through tropes of nationalism rooted in economic marginalization, loss of territory, and anxieties about invasions of home. Such anxieties give rise to the securitization of fear used to underwrite the allocation of resources to fortify borders and manage risk. The securitization of fear and its geopolitical uses and abuses in the context of disaster, conflict, and human displacement demand further attention. This article examines two expressions of fear that have significant implications for broader research agendas in political geography. First, in post-tsunami Sri Lanka, the implementation of "buffer zones," or no-build setback areas along the affected coastlines after the tsunami vividly illustrates how efforts to enhance public safety can stir feelings of discrimination, tension, and fear. Humanitarian remedies that are not cautiously conflict-sensitive can unwittingly generate fear and mistrust. Second, the politics of fear intersect with the provision of international aid, which is increasingly premised on vulnerability "at home" in donor countries to make it politically relevant. Once created, such crises are offset by aid to locations that represent geopolitical threats. Unraveling the ways in which fear is produced and framed to justify violence, exclusion, and hatred is a pressing political and intellectual task within geography. Key Words: aid, fear, nationalism, Sri Lanka, tsunami.
\end{abstract}

$\Gamma$ he tsunami of 26 December 2004 led to extraordinary devastation and destruction for people of the Indian Ocean Basin region. Aid from overseas was unprecedented; more than $\$ 13$ billion was pledged, with $\$ 5$ billion coming from private individuals and companies (The Economist 2005). ${ }^{1}$ Several of the states affected by the tsunami had been host to longterm conflicts before the disaster, raising the question of what impact the tsunami and related reconstruction aid might have on conflict (Le Billon and Waizenegger 2006). More than two years later, the results are mixed. In Aceh, the Indonesian Government signed a peace agreement with the Free Aceh Movement (GAM) in August 2005 that was still holding early in 2007. In Sri Lanka, developments since the tsunami have intensified the country's prolonged political crisis (Uyangoda 2005). Government responses to the tsunami and the politics of aid distribution generated feelings of discrimination and mistrust among Muslim and Tamil communities, which were hardest hit. Although not directly attributable to the tsunami, conflict between the rebel Liberation Tigers of Tamil Eelam (LTTE) and the Government of Sri Lanka (GoSL) has escalated, resulting in the resumption of war.

Responses to the tsunami have not taken place in a political vacuum. In Sri Lanka, "Struggles over in- terethnic justice, neoliberalism, economic distribution, the disempowerment of women, caste bigotry and such have shaped the [Sri] Lankan political landscape in significant ways over the last decades ... even the tsunami cannot wipe out the imprint of these fault lines" (Nesiah, Nanthikesan, and Kadirgamar 2005). The devastation of the tsunami and the geographies of aid that followed overlay long-standing geopolitical tensions and political geographies of displacement (Hyndman and de Alwis 2004; Nah and Bunnell 2005). People displaced by the war in Sri Lanka, for example, were displaced again by the tsunami. Exacerbating this situation, many international nongovernmental organizations neglected to consult their national and local counterparts in the immediate aftermath of the tsunami (Couldrey and Morris 2005; Institute for Policy Studies 2005).

I examine the politics of fear and vulnerability in posttsunami Sri Lanka as part of a larger project in political geography to unravel the production of fear and its political corollaries. I do so in two parts. First, I trace geographies of fear and enmity within Sri Lanka generated in the aftermath of the tsunami through the government's policy of buffer zones, or no-build zones, established early in 2005. This geography of fear also has a transnational dimension, traversing international borders as well as different nations within Sri Lanka. 
Second, extending this analysis, I demonstrate that international aid is closely linked to geopolitical fears that traverse international boundaries. Both buffer zones and international aid use fear to rationalize their implementation and unwittingly produce anxiety and conflict in their wake.

The use of extraordinary measures to secure borders against geopolitical threats, such as unwanted migrants, is not particularly new (Mongia 1999). The production of crises, including the fear and xenophobia they instill, remains a pressing concern because they legitimate grounds for exceptional interventions (Agamben 1998; Mountz 2004). States produce crisis and fear to obtain consent for securitization measures. Probing the ways in which fear is made and used in contexts of disaster and aid is crucial to contesting the violence, exclusion, and hatred they produce.

\section{The Production of Fear}

Sleepless in the early hours, you make a nest out of your own fears-there must have been survival advantage in dreaming up bad outcomes and scheming to avoid them. This trick of dark imagining is one legacy of natural selection in a dangerous world.

-Ian McEwan, Saturday, 2005

The expansion of fear also comes from geopolitical fearmongering and intense conflicts from Darfur to Iraq. It comes from our growing apprehensions about inequality, social injustice and political instability across the globe. ... Fear plays many roles in consolidating the nation and in legitimating government actions.

-Victoria Lawson, "Natural Disaster or Space of Vulnerability," 2005

The tsunami of late 2004 generated an unprecedented global outpouring of aid that raises interesting geographical questions as to why people cared to give so much to tsunami relief in comparison to other kinds of humanitarian emergencies. Fear is one explanation for this philanthropic impulse given the stark witnessing of "white death" that occurred on television screens worldwide (Olds, Sidaway, and Sparke 2005). Just as "our deaths" appear to matter more than "their deaths" in Iraq and Afghanistan (Hyndman 2007), the valence of "white death" was greater than indigenous death after the tsunami. Media coverage of the victims and survivors of the tsunami, many of them Euro-American tourists, generated a frightened sentiment among audiences in the global North that "it could have been me." Although this fear of the tsunami is geographically selective and racially skewed, it was transposed into a hopeful if charitably unequal moment of unprecedented philanthropy (Jeganathan 2005). The tsunami created a space of exceptionalism and crisis: blameless victims captured on camera stirred fear in those who witnessed the devastation. Yet, in comparison, the destruction and loss of life from the immense earthquake that struck Pakistan in 2005 hardly registered among private donors of the global North (Grundy-Warr and Sidaway 2006).

\section{Making Nationalism}

The production of fear can be traced to the rise of nationalisms. Vulnerability cultivates fear, sometimes for political purposes. Fear has been incited through strategic tropes of nationalism that stir feelings of threat and potential loss, as then-Serbian-President Slobodan Milosevic so successfully managed in his 1989 speeches about Kosovo, a historical Serbian homeland allegedly taken over by ethnic Albanians (Glenny 1992). In so doing, he sowed the seeds for his plan to ethnically cleanse the province of Kosovo of ethnic Albanians a decade later. Militarized Serbian nationalism also confronted Croatian nationalism when Croatian leaders followed Slovenia's lead in 1991, declaring independence from Belgrade and the country of Yugoslavia, but claiming territory that was home to many Serbs. The subsequent conflict in Croatia and Bosnia from 1992 to 1995 was a war of competing nationalisms over territory and people in which fear was used to fuel hatred and violence. The destructive power of nationalism was most evident in Bosnia-Herzegovina, a fledgling state struggling for existence against the wishes of Belgrade and its remnants of Yugoslavia (Ó Tuathail 2006).

In Sri Lanka, nationalism incites fear among Tamil, Muslim, and Sinhala ethno-national groups. The framing of conflict has been predicated primarily on oppositional tropes of Tamil-Sinhala relations, but at different times the Sri Lankan Muslims have been allies to each side. School textbook representations of Sinhala rulers in relation to their Tamil opponents, for example, subscribe to a fairly obvious state-sponsored Sinhala nationalism as part of the national curriculum (Siriwardene et al. 1982). In a subsequent analysis of school texts, de Alwis (1998) challenges the "us-them" binaries behind these chauvinistic stories, and yet notes their importance in inculcating children with specific imaginaries of nation. She demonstrates that tales of military vulnerability generate fear, followed by sentiments of courage and victory in the name of the nation. These nationalisms have become vehemently militarized and perceived as "ethnic" hatred, despite more subtle historical 
geographies of fear. Where marginalization, exclusion, and related vulnerability produce fear, violence is one response.

The production of nationalism in Sri Lanka is also linked to World Bank-induced reforms to liberalize the economy in 1977 (Hyndman 2003). Before 1977, state socialism allowed the government to funnel funds to specific groups, making concessions especially to the Sinhalese rural middle and lower classes in order to be returned to power (Stokke 1998). After independence from Britain in 1948, political power was organized according to class more than to national identity or ethnicity (Jayawardena 1990). Neoliberal economic policies signaled the end of the concessions that had held ethnic and class alliances together. Private investment began to flourish among some groups despite the conflict, but Tamil areas in Sri Lanka's Northeast and Sinhala areas in the rural South remain largely excluded from this prosperity (Sivanandan 1990).

In this context, economic marginalization produced fear and uprising among two groups excluded from the spoils of prosperity under a new neoliberal regime. The first was comprised of Sinhala youth from rural agricultural and middle classes who later formed the JVP (People's Liberation Front), and the second was made up of a cadre of Sri Lankan Tamils, namely the Tamil Tigers, who armed themselves against the government (Gunasinghe 1987). Both groups used militarized nationalism and violence to advance their struggles.

Random violence that invokes public fear and kills unsuspecting civilians is one response to exclusion and marginalization. Such militarized violence characterizes the LTTE's bombing of public places and people during the mid-to-late 1990s. More recently, in 2006, targeted attacks by the LTTE resumed, as did violent expressions of Sinhala chauvinism against Tamils. The Sri Lankan army and police have also been responsible for a litany of abductions, deaths, and other human rights violations, especially in the Eastern Province, since the war began in 1983. These acts of violence have fueled oppositional nationalist movements on both sides of the majority Sinhala/minority Tamil divide. Militarized nationalism, whether Tamil or Sinhala, is about spatializing fear.

\section{Under Siege: Home and Native Land}

Alison Mountz (2003, forthcoming) and William Walters (2004) argue that security measures transcend the political borders of any single nation-state; such measures are organized increasingly on a transnational basis. Mountz shows how the state operates far beyond its territorial borders through airline carrier sanctions, offshore screening of passengers by airline liaison officers, and visa restrictions to exclude asylum seekers and other migrants. Walters introduces the complementary concept of "domopolitics" to suggest the central place of the home (domus) in geopolitical discourse:

Domopolitics implies a reconfiguring of the relations between citizenship, state, and territory. At its heart is a fateful conjunction of home, land and security. It rationalizes a series of security measures in the name of a particular conception of home. ... The home as hearth ... as our place, where we belong naturally ... home as a place we must protect.

-(Walters 2004, 241)

Home is rendered as a secure, reassuring place characterized by trust, togetherness, and familiarity. By definition, people from unknown places must be invited "home." A bifurcated sense of security, represented as both prosperity (economic) and risk (political), requires different treatments on the part of the state. Discourses of neoliberal globalization are not inconsistent with state discourses of securitization: let in skilled, elite migrants but keep the suspicious, uninvited ones at bay. This is what Matt Sparke calls "securitized nationalism ... the cultural-political forces that lead to the imagining, surveilling and policing of the nation-state in especially exclusionary but economically discerning ways" (Sparke $2006,153)$. The endangerment trope of invasion produces fear and is underwritten by securitization, a governmentality based on mistrust and fear of the uninvited other (Bigo 2002).

The securitization of fear is a politically powerful resource for states that need legitimate grounds for extraordinary measures, such as violent exclusion from their territories. Yet "government practices of border control do not simply defend the 'inside' from the threats 'outside,' but continually produce our sense of the insiders and outsiders in the global political economy" (Amoore and de Goede 2005, 168). The securitized nationalism Sparke identifies, the discursive distance it produces, and its implied boundary between "us" and "them" represent a deeply geographical problem that allows fear to be fostered and to fester if left unchallenged. Both the ethno-nationalisms of Sri Lanka and the securitized nationalism of home are militarized geopolitical projects that spatialize fear in specific ways.

After a note on Sri Lanka's political context, the remainder of the article examines two ways in which fear is deployed in spatially strategic ways in the Sri Lankan context: first, through an evolving government policy of "buffer zones," and, second, through the use of fear in creating a kind of domo-nationalism in the global North that promotes particular geographies of aid. I contend that the buffer zones have exacerbated feelings of 
discrimination and nationalism along the coasts of Sri Lanka, fueling tensions and conflict in the country, and that international aid to Sri Lanka is both an antecedent to conflict in the country and a tool for managing the risk of such conflict spilling over into donor countries. Both cases show how fear is produced by and through specific political geographies of insecurity.

\section{The Sri Lankan Political Landscape}

Two key moments of political geography begin to illustrate the relations of fear and mistrust among particular sectors of Sri Lankan society. First, on 23 July 1983, members of the LTTE ambushed an army patrol on the Jaffna Peninsula, a predominantly Tamil area, and killed thirteen soldiers. In the hours that followed, government troops in Jaffna took revenge and killed fifty-one unarmed Tamil civilians (Swamy 1996). In Colombo the next day the government decided to publish, broadcast, and televise the news about thirteen soldiers being killed by the LTTE (aka Tamil Tigers) while blacking out news about reprisals by the armed forces. By 25 July, anti-Tamil violence had spread throughout the city, enabled by the government's decision and by the police who largely stood by and witnessed the looting of Tamil businesses, murder of Tamil civilians, and widespread displacement of Tamil residents in the capital.

Later, in 1990, more than three hundred Muslim men and boys were prostrate in prayer at the Meera Jumma Mosque when a power cut threw the mosque into darkness and LTTE cadres opened fire and killed 140 men and boys, shooting most of them in the back. In Eravur two weeks later another 173 Muslim men, women, and children were murdered in an effort to ethnically cleanse Muslims from Tiger-controlled territory, or at a minimum displace them from their homes to shanty villages along the beach, between lagoon and sea (Ismail 1995).

The war in Sri Lanka has been characterized as one of violent competing nationalisms between the LTTE and the Government of Sri Lanka's armed forces since the pogroms of 1983 (Jayawardena and de Alwis 1996). But Sri Lanka's present is an expression of a long history and geography of struggle well-documented by Sri Lankan and Sri Lankanist scholars (Abeysekera and Gunasinghe 1987; Spencer 1990; Jeganathan and Ismail 1995; Thiruchelvam 1996). The conflict has spawned large-scale displacement within the country and well beyond its borders, where a significant Sri Lankan Tamil diaspora has emerged from this country of just under twenty million people (Daniel 1997; Fuglerud 1999). The death toll as a result of the conflict exceeds sixty-five thousand people.
In February 2002, a ceasefire was signed, allowing the economy to be rebuilt and enabling the LTTE to engage with the government and wider society as a political entity rather than as a separatist movement or "terrorist organization" ( J. Perera 2005). In June 2003, with the prospect of peace ripe in the minds of international donors, a conference was held in Tokyo to finance the reconstruction of war-torn Sri Lanka, at which US\$4.5 billion was pledged for the "Regaining Sri Lanka" strategy. The LTTE did not attend the conference, which aimed to provide financial incentives to peace. Much of this funding was held back because the government and LTTE could not agree on how to distribute the funds. Resolving governance issues between these federal-provincial scales has become one of the most pressing issues in both the pre- and post-tsunami period. Plentiful international aid begs the question of how, by whom, and on what it should be spent.

Ceasefire violations escalated in 2004 and political assassinations reached a critical peak in 2005. After buffer zones were implemented early in 2005, tsunami reconstruction has taken place alongside and in concert with rising political tensions among ethnic groups and bipartisan party politics. More than a thousand people were killed in 2006, including an unprecedented attack on seventeen staff working for an international relief organization who were murdered en masse in August (Apps 2006).

\section{The Case of the Buffer Zones in Post-Tsunami Sri Lanka}

When the buffer zone made its entrance after the waves had left behind the destruction [in January 2005], it was known by another name, less popular-set back zone. It most certainly has lived up to that title. —Amantha Perera, "The Buffer Zone Fiasco," 2005

In January 2005 the Sri Lankan Cabinet of Ministers legislated buffer zones ostensibly as a public safety measure against the potential devastation of another tsunami (Centre for Policy Alternatives 2005; Jansz 2005). In the densely populated South, dominated by a Sinhala majority and international tourism, a 100-meter buffer zone was established. In the Tamil- and Muslimdominated Eastern Province, where tsunami-related devastation and damage proved greatest, a 200 -meter buffer zone was declared. In both areas, the high density of population and scarcity of land made the setbacks highly contentious. At the time, the Opposition noted that Clause 14 of the Sri Lankan constitution guarantees 
people the right to live in areas of their choice. The Opposition said it would rescind the buffer zone requirement if elected to power, immediately politicizing the apparently arbitrary buffer zone decision (Tissera 2005). The buffer zones created contested political spaces characterized by polarized party politics, and an "opportunity to fish for votes" (de Alwis 2005). Land within any buffer zone could still be used for business purposes, a particularly important concession for tourist operators in Sinhala-dominated beach areas of southern Sri Lanka (MONLAR and ANRHR 2005). Operators of beach hotels that were damaged but not destroyed by the tsunami could and quickly did restore their properties and continue business as usual.

Creation of these "no build" areas was intended to move people's residences away from the coast in an effort to prevent deaths should another tsunami occur; however, no research, rationale, or examples of how this approach would work or had fared elsewhere were provided at the time of their introduction. As the Institute for Policy Studies (2005) in Colombo stated, if public safety was the prevailing aim, the buffer zones should have been equivalent for all areas. No explanation was offered that specific environmental, social, and physical characteristics of coastlines in different parts of the country ostensibly required responses tailored to those geographies. Instead, Sri Lanka's World Bank representative, Peter Harrold, has noted that buffer zones have been the single greatest barrier to progress in housing reconstruction for those who lost their homes in the tsunami (cited in Dias 2006). For those who had lost family members and their homes, the prospect of losing their property and places of work (many were fishers) to no-build zones was a highly unpopular decision, creating even more uncertainty in the wake of the disaster. This apparent geographical "fix" served instead to fan the flames of political controversy between the major political parties and among the various ethno-national groups that constitute the Sri Lankan populace, namely Sinhala, Tamil, and Muslim groups.

The President's Office announced that the government would identify lands closest to the affected villages and build a house for "every affected house owner who lived within the said 100 metres" (Sambandan 2005). It specified that any owner of a home within the 100 -meter zone "will retain the ownership of his original land" and the government "will not in any way claim ownership to such property." Moreover, the owner would be "entitled to appropriate the land (within the 100-metre-zone) as he wishes, except building on it." The government would "extend patronage to planting coconut or any other suitable crop in those lands" (Sambandan 2005).
In June 2005, a poll of those displaced from these areas showed that 65 percent shunned the idea of the buffer zone (Kangararachchi and Range 2005). In the North and Northeast, a 400-meter buffer zone was declared by the LTTE, an assertion of its declared sovereignty in those areas (Jeyeraj 2005).

Because so much more land was rendered "out of bounds" in the Eastern Province compared to the Sinhaladominated South, those displaced by the tsunami in the East, the minority Tamils and Muslims, claimed discrimination by the Sinhala-dominated government. Fishers staged several protests against the government's edict (Associated Press 2005). Through the buffer zone legislation, narrow strips of land between the sea and lagoons, called littoral, or eluvankaral in Tamil, and once home to separate Muslim and Tamil villages, were declared "unlivable" by the government. The hinterland, or paduvaankaral, inland from (and west of) the lagoon is occupied largely by Sinhalese persons resettled there by government colonization schemes during the more nationalist periods of the 1950s and 1970s (Jeyeraj 2005), making it less hospitable to Tamils and Muslims displaced from the coast. In the town of Kalmunai, Ampara District, where damage was assessed as the worst, 135,000 people were packed into seven square kilometers; about 4,000 of them died in the tsunami. The most intransigent resettlement problem has been where to put the tsunamidisplaced, even on a temporary basis. In Ampara District, land is most scarce, population most dense, and human displacement most acute in the post-tsunami period (Institute for Policy Studies 2005).

The zones served to displace yet again those dispossessed by the tsunami and to reproduce patterns of apparent discrimination against minority Tamils and Muslims. Many of those displaced by the tsunami in the hardest hit eastern districts of Batticaloa and Ampara had already been displaced by the conflict, in some cases repeatedly, to makeshift seaside homes that were swept away by the tidal waves. Ironically, the dramatic dispossession caused by the tsunami brought to light the endemic displacement of so many members of these communities forced to move to seaside locations to escape the war (Grundy-Warr and Sidaway 2006). The war, the tsunami, and the buffer zone response each constitute a layer, or moment, of displacement for those in these two eastern districts.

Not only did the government generate fears that Muslims and Tamils were being discriminated against in terms of lost land and tsunami aid, it mobilized fear of another tsunami to gain support for its legislation. On 28 March 2005, an earthquake near the epicenter of the tsunami registered 8.7 on the Richter scale. 
Then-President Chandrika Kumaratunga stated that the mere occurrence of the earthquake (which did not create a tsunami) was a logical rationale for the buffer zone: "the people now should realize that the government, bearing in mind all allegations leveled against it, has acted prudently with a vision and in a responsible manner" (Associated Press 2005). Soon after, an opposition MP and former minister, Ravi Karunanayake, retorted that in his riding of Crows Island 1,500 National Housing Development Authority houses went underwater in the tsunami, despite the fact that they were situated more than 100 meters from the shorelineproof, he said, that the buffer zone would be ineffectual.

While the initial conception of $100-\mathrm{m}$ and $200-\mathrm{m}$ buffer zones (and 400-m in LTTE-controlled areas) remained politically and scientifically suspect, the government of President Chandrika Kumaratunga adamantly maintained the policy for almost a year, though it referred it to a body of foreign experts for consultation (Fernando 2005). Cracks in the government line only began to show late in her presidency, in October 2005, when the Advisory Council of the Coast Conservation Department approved exemptions from the buffer zone policy (Cassim 2005). Although most criticism of the buffer zones was homegrown (de Alwis 2005), some observers attribute the shift toward exemptions to former President Clinton's assessment during a May 2005 visit to Sri Lanka that the buffer zones were impractical. As one journalist wrote, it "was after the Clinton remarks that the government woke up to reality" (A. Perera 2005). In November 2005, Sri Lanka elected a new president, Mahinda Rajapske, from the same political party as the former president, Chandrika Kumaratunga.

After his election, the new president changed the name of his predecessor's tsunami response body from the Task Force to Rebuild the Nation (TAFREN) to the Reconstruction and Development Agency (RADA). In February 2006 RADA announced in an ad in the Sunday Times that the buffer zone "set back standards" would be relaxed and retrofitted to follow the Coastal Zone Management Plan of 1997 (RADA 2006). ${ }^{2}$ The Coastal Zone Management Plan adopted by the Sri Lankan government in 1997 had not been enforced given the widespread displacement of people by conflict to coastal areas in the East. The plan allows for setbacks of 35-125 meters from the high tide watermark. Given the Plan's existence prior to the tsunami and its environmental safeguards couched in a scientific rationale, setbacks that appear to correspond to specific local conditions are less politicized than their predecessors. Revised and more lenient buffer zones remain in place throughout the country, delaying the reconstruction of replacement homes until land on which to build can be found and allocated (Centre for Policy Alternatives 2005).

A preliminary study of security in temporary shelter encampments on the east coast suggests that fear for personal safety is prevalent among residents. Precarious geographies of trust and relative peace before the tsunami appear to have been replaced with new community formations and the unfamiliar faces of those who are often searched and questioned about their identity (Hyndman 2006). ${ }^{3}$ The temporariness of their shelter is also in question, as the vast majority of those who lost their homes in the buffer zones have yet to have new ones allocated to them (Centre for Policy Alternatives 2005).

The buffer zones have created spaces of fear and mistrust around which party politics and nationalist tensions are organized. Fear of another tsunami has been used to legitimate buffer zones, and now-extant conservation guidelines are being used as a more scientific marker of setbacks. The setbacks, literal and figurative, have generated uncertainty and hopelessness regarding the reconstruction of permanent homes. Measures implemented in the name of public safety have had precisely the opposite effect, generating communal tensions, personal insecurity, and everyday fear among those in temporary accommodations in the Eastern Province.

\section{The Geopolitics of Conflict and Aid}

It is a conviction of the times, this compulsion to hear how it [TV news] stands with the world, and be joined to the generality, to a community of anxiety ... a different scale of news value has been set by monstrous and spectacular scenes. -Ian MacEwan, Saturday, 2005

Cultures of domination rely on the cultivation of fear as a way to ensure obedience. ... As a culture we are obsessed with the notion of safety.

$$
\text { —bell hooks, All About Love, } 2000
$$

Fear is a powerful emotion and tool mobilized to achieve various outcomes, political and otherwise. The securitization of fear involves the rehearsal of looming threats and invasion, particularly in the register of affect, to strategically shift political support for state policies and measures. Speaking of the U.S. role in Iraq, Ó Tuathail $(2003,857)$ asserts that "the world's most powerful military today is led by a cabal of restless nationalists immersed in an anti-intellectual culture of affect and aggressive militarism." He reiterates William Connelly's argument that human thought is not merely representational but also "enactive" as affect (Connelly 2002). Affect, not just argument, shapes political life. 


\section{Development as Security}

Concerns about survival, security, and sovereignty are intimately linked to the production of fear at multiple scales: of individual property owners, of minority national or ethnic groups, of states that see themselves under siege. Fear is also used to set in motion political demands for protection from often ill-defined, geographically diffuse threats: disease, asylum seekers, transnational crime, terrorism, all ostensibly linked through a global web of risk. Individual states may recognize shared insecurity and join forces on disease prevention, border protection, asylum policy, and intelligence related to transnational criminal activity.

Immigration regulations and border controls are among the most common sites of "securitization," but foreign policy and development aid have also become fertile ground for cultivating fear about the proliferation of conflict and its consequences in governments of the Global South. The United States, Britain, Canada, and the Netherlands have integrated development aid with foreign policy through this security discourse, coupling it with concern that aid be given where it can be most effective. Ultimately, these donor countries argue, aid effectiveness relies on political stability, good governance (low levels of corruption being one indicator), and neoliberal economic policies. Ironically, at the other end of the migration spectrum, fear of poor migrants arriving uninvited and leaning too heavily on their precarious welfare states is a major concern for these same donor countries, particularly in Europe where publicly-funded services and infrastructure have historically been more generous. The integrated development and humanitarian assistance has become a de facto political tool for engaging countries that are not strategic to donors in terms of foreign policy or trade, but that may prove potentially threatening to donor states without intervention (see the discussion paper of the Canadian International Development Agency: CIDA 2001).

On a more hopeful note, insecurity can instigate political will to address the social and economic disparities that lead to conflict. In their analysis of aid policy developments in Britain, David Slater and Morag Bell examine the 2000 White Paper of the Department for International Development (DFID): "there can be no secure future for any of us-wherever we live-unless we promote greater global social justice" (Slater and Bell 2002, 347). For the political constituency that once believed overseas development funds could be better spent at home, this trope denies and defies the geographical separation of "here" and "there," albeit in a politically retrograde manner. The "distinction between domestic and international policy is increasingly blurred" (Slater and Bell 2002, 347). Foreign aid and development assistance to address material inequalities and political abuses are "for our own good," the well-being of donor societies.

In a similar if more fearmongering vein, Canadian aid policy documents rehearse related tropes:

Interdependence means that there is a convergence of interests among states around a wide array of issues-the environment, peace and security, health and the suppression of disease, economic and financial stability, migration and transnational crime. All states have interests in these issues-which can also have a strong values base-and advancing these interests requires, to a growing extent, improved international cooperation.

-(CIDA 2001, 4)

In short, "Canada's border is long and open to both commerce and people. Since disease does not need a visa, we cannot be healthy in an unhealthy world" (CIDA $2001,6)$. Health and well-being at home demand international cooperation with other states. Foreign policy, including aid flows, can manage these geopolitical threats.

The mobilization of fears that the "Third World" might leak into the "First World" has become a compelling way to frame development assistance as foreign policy and a security issue. Since aid policy in Canada became linked in 2000 to security matters and foreign policy, development aid has increased 8 percent per year. Insecurity is expressed at different scales and from multiple perspectives: migrants, for example, at once fear the states at whose borders they arrive and yet embody insecurity in the imagination of those same states (Mountz 2004). But as Gregory $(2004,28)$ asks, "how did those imaginative geographies solidify architectures of enmity that contrived to set people in some places against people in other places?" How are vulnerability and fear used to underwrite hate and violence? More hopefully, how can it be diffused and taken apart before it does its destruction?

With some exceptions, few geographers have examined aid policy as foreign policy. And yet the implications of these new ties between aid and security usher in a distinct geographical imagination and constellation of geopolitics. Increasingly, donor agencies align humanitarian and development assistance with issues of (in) security and (in)stability (Macrae and Leader 2000). Threats produce fear; fear produces a political willingness to act or acquiesce to policies and practices that might not otherwise be acceptable, a securitization of fear.

An often-unstated role of development agencies is to manage risk associated with developing countries (a) by 
providing development aid where it will stabilize a developing country and increase its economic growth, or ostensibly (b) by withholding aid to "rogue" states until they come into line with donors' criteria for aid. By making development assistance conditional on "good governance" in recipient countries, donors can indirectly address geopolitical threats. Western states essentially establish their own political model as a prerequisite for obtaining assistance, which is then used to address foreign policy concerns. ${ }^{4}$ Risk appears to be managed on the one hand through neoliberal policies of aid and trade that engender security and prosperity and on the other through policies of securitization built on tropes of threat that inculcate fear. As Didier Bigo $(2002,63)$ has argued, "expansion of what security is taken to include effectively results in a convergence between the meaning of international and internal security." Evoking fears at home of "over there" through a state-sponsored nationalism is politically persuasive. Fear and insecurity are linked across scales, from the bodies of migrants who represent insecurity in the imagination of states to the bifurcated transnational networks of biopolitical surveillance (Sparke 2006). Fear creates a crisis in search of a response.

\section{Aid and the Tsunami: "The Difference between $\mathrm{AD}$ and $\mathrm{BC}$ "}

The geopolitics of international aid to the tsunamiaffected countries of the Indian Ocean Basin vary immensely across the region. Geographers of diverse backgrounds have had much to say about tsunamis and their impact (see, among others, Glassman 2005; Lawson 2005; Marston 2005; Nah and Bunnell 2005; Seager 2006; Le Billon and Waizenegger 2006). In the Sri Lankan context, there is evidence that the tsunami shaped aid disbursements and practices, in some cases dramatically. I briefly refer to the case of Canadian aid and decisions around its distribution after the tsunami because they illustrate more hopeful transnational geographies of aid and geopolitics.

The tsunami underscored the geopolitical value of Sri Lanka to Canada during a time when Canada was preparing to phase out foreign assistance to Sri Lanka. In interviews during June 2002 with senior managers at the Canadian International Development Agency in Ottawa, I was told that Sri Lanka would be cut from the Canadian aid map during CIDA's reorganization and reduction of aid recipients. Sri Lanka's human development indicators were considered too high, with the best gender equality indicators in the region and less acute poverty than its Pakistani, Indian, and Afghan neighbors (Interviews 12 and 13, 2002 $2^{5}$ ). By 2005 the geopolitical climate for Canadian aid to Sri Lanka was transformed: "The tsunami changes everything," said the then Canadian High Commissioner for Sri Lanka in Colombo. She asserted unequivocally that Canada was not leaving Sri Lanka in terms of bilateral aid, technical assistance, or knowledge transfers, and noted that the post-tsunami visit of Prime Minister Martin in January 2005 cemented Canada's and CIDA's role for the next decade (Interview 25, February 2005). At the CIDA office in Colombo this sentiment was echoed by two senior program officers who confirmed that the tsunami put Sri Lanka "on the map." One of them noted that it could still fall off again but described the "tsunami effect" as "a difference between BC and AD" (Interview 9, February 2005) ${ }^{6}$

In April 2005, CIDA released its list of twenty-five "development partners," the focal point of its bilateral aid programming for the next five years (CIDA 2005a). The list is dominated by fourteen very poor African countries, but also includes the more prosperous though tsunami-devastated states of Sri Lanka and Indonesia. CIDA notes that its goal is to concentrate at least two-thirds of bilateral aid to these twenty-five states by 2010 (CIDA 2005b). The reasons for this dramatic shift in policy remain an open question ripe for further research, but the political influence of the Sri Lankan Tamil diaspora is sizeable. Three senior managers in two Ottawa-based interviews acknowledged that geographies of immigration and, in particular, the influence of diasporas in Canada add pressure for continued aid to places like Sri Lanka and Pakistan (Interview 12, June 2002; Interview 35, July 2005).

The transnational politics of the diaspora are worthy of attention because Canada hosts the single largest Sri Lankan Tamil diaspora in the world (McDowell 1996). Estimates of the Tamil diaspora in Canada range from 200,000 (Wayland 2004) to 400,000 (Sriskandarajah 2002), and Toronto is "the city with the largest number of [Sri Lankan] Tamils in the world" (Cheran 2000, 170). Most Sri Lankan Tamils are concentrated in a handful of Toronto-area political ridings, leveraging their political influence among politicians. Toronto has been a locus of Tamil nationalism and financial support since refugees and their family members sought asylum in Canada in the late 1980s (Cheran 2000). The significance of this immigration stream cannot be underestimated. Between 1991 and 2001, Sri Lanka was the fifth largest source country of immigrants to Canada after China, India, the Philippines, and Hong Kong (Statistics Canada 2001). The government agency Citizenship and Immigration Canada reports that from 1998 to 2000, Sri Lanka was the second largest 
refugee-sending country to Canada, accounting for approximately 10 percent of the refugee population in each of those years (CIC 2001).

The retrograde shock of "white death" after the tsunami, in conjunction with the more constructive lobbying of the Canadian government by the Sri Lankan Tamil diaspora, served to heighten the political visibility of Sri Lanka in Canada in the aftermath of the disaster. ${ }^{7}$ The geopolitics of aid linking Canada to Sri Lanka have been traced through diasporic patterns of displacement, forced migration, and political struggle. State-sponsored nationalism and securitized fear in defense of "home" and its imagined boundary between "us" and "them" are partially broken down by diasporic struggles to make "them" "us" during crisis.

\section{Conclusion}

Have his anxieties been making a fool of him? It's part of the new order, this narrowing of mental freedom, of his right to roam. ... He suspects he's becoming a dupe, the willing, febrile consumer of news fodder, opinion, speculation and all of the crumbs the authorities let fall. He's a docile citizen watching Leviathan grow stronger while he creeps under its shadow for protection.

-Ian MacEwan, Saturday, 2005

Fear serves many functions as an imperative for aid policy and a rationale for buffer zones in the wake of a tsunami. Threats of invasion, whether by refugees, disease, or transnational crime, are used to underwrite aid policy and actual flows. Insecurity drives aid politics in donor countries by producing a trope that people there will be safer if they help stabilize conflict and disaster elsewhere. This article has exposed some examples of geopolitical uses and abuses of fear in the context of disaster, conflict, and displacement. Both the ethno-nationalisms of Sri Lanka and the securitized nationalism of home are geopolitical projects that spatialize fear in specific ways.

Buffer zones and international aid are but two disaster prevention measures that aim to manage risk in climates of fear. Just as fear creates grounds for suspicion, it needs to be treated, both intellectually and politically, with suspicion. Unraveling the antecedents of fear is crucial to keep governments and other protagonists of nationalism in check. Without constant vigilance that probes the production of fear and crisis, both of these commodities will be used creatively and strategically to justify violence and exclusion. Insecurity expressed at scales of the body and household will remain largely effaced if militarized nationalisms continue to reproduce geopolitical life as a matter of nations and states, fear and violence.
International assistance is underwritten by tropes of risk management, disaster prevention, and the securitization of fear. A transnational geopolitics of diaspora with antecedents in conflict and forced migration elucidates the constructive political persuasion of refugeescum-citizens in their new home. In a more hopeful vein, fear can be unraveled, discounted, and negotiated to subvert the fears of the docile citizen. Fear forges vital connections between the citizens of donor states and recipient ones, whether based on tropes of solidarity-in-adversity or of potential invasion from the global South. But fear can also be transformed into hope where binaries between "us" and "them" are broken down, in this case by diasporic publics in the North as well as anti-chauvinist coalitions in the South. ${ }^{8}$ Aid flows can change where political support demands it, as in Canada's aid relations with Sri Lanka. Beneath the state-centric guises of securitized nationalism (Sparke 2006), illegal migrant crisis (Mountz, forthcoming), and domopolitics (Walters 2004) remain spaces of hope and possibility.

Challenging the production of fear by states, multilateral institutions, and militant nationalists is a vital source of hope and change in an emerging political climate of mistrust and geographical exclusion (Hyndman 2005). Echoing the words of Nesiah, Nanthikesan, and Kadirgamar (2005), "In honor of the dead then, let us make this moment of collective mourning also an opportunity to make a commitment to an ethos of pluralism, human security and democratization."

In Sri Lanka, the initial arbitrariness of the buffer zones infused the already precarious politics of ethnicity, class, and gender with new tensions, generating more polarization and grounds for conflict. Buffer zones are underwritten both by fear and a claim to future security, however unproven. Nanthikesan (2005) cautions against focusing on the tsunami-affected to the neglect of those who fled fear of death or persecution, displaced by class and ethno-national wars:

Speaking of disasters and those who lost their livelihoods in the span of a few minutes, we are reminded of the Muslims of the North who were driven out by the LTTE on few hours notice. These refugees continue to languish in refugee camps for over fifteen years without any serious RR [relief and reconstruction] effort. It will be difficult for these refugees to understand why everyone around the globe who are trying to assist their eastern brethren, have paid no attention to their fate ... [the] homeless beggar in the streets of Batticaloa may wish she was affected by the tsunami rather than by structural poverty that had deprived her livelihood.

The tsunami and its aftermath have produced their own class fractions, cultural exclusions, and nationalist fears, 
none of which serve to mitigate the current conflict. Climates of fear are, however, made not given. As geographers, unraveling the ways in which fear is produced and framed to legitimate violence, provoke communal tension, and increase the discursive distance between "here" and "there" exposes grounds for hope.

\section{Acknowledgments}

I would like to thank Vicky Lawson for her fearless engagement with this manuscript. Matt Sparke, Philippe Le Billon, Mala de Alwis, and Alison Mountz all provided insightful comments, as did Annals editors and referees. Research on which this article is based was generously supported by the Social Sciences and $\mathrm{Hu}$ manities Research Council of Canada.

\section{Notes}

1. In the Sri Lanka context, another $\$ 2.2$ billion was pledged for tsunami reconstruction at the Kandy Donor Conference in June 2005 (Institute for Policy Studies 2005). Agreement between the government of Sri Lanka (GoSL) and the rebel Liberation Tigers of Tamil Eelam (LTTE) on how to spend aid allocated for tsunami reconstruction is one of the most pressing issues in the post-tsunami period.

2. The Plan was implemented in 1981 with a mandate for renewal every four years. The most recent plan in place at the time of the tsunami was the 1997 version (Centre for Policy Alternatives 2005).

3. Much of the research for this article and the 2006 study cited took place during two visits of approximately one month each in February 2005 and 2006. In 2005, I worked with UNICEF post-tsunami to assess sexual and gender-based violence. In February 2006, forty interviews with widows and widowers in Batticaloa and Akkaraipattu were conducted to ascertain changes in security, the gender division of labor, and marriage practices in the wake of the tsunami.

4. Slater and Bell's (2002) postcolonial approach to analyzing development asks, "who are the agents of knowledge, where are they located, for whom do they speak, how do they conceptualize, where are the analytical silences, who is being empowered, and who is being marginalized?" (339).

5. Interview information is provided in Primary Sources, following the References.

6. Canadian bilateral aid will continue to be disbursed in the unusual manner that has characterized the past fifteen years, whereby no Canadian aid is provided directly to the Sri Lankan Government (nor to the LTTE) for their use. Rather, all bilateral funds are distributed through nongovernmental organizations and civil society networks with proven track records.

7. One should not be too optimistic about the coherence and unity of the Sri Lankan diaspora. In Toronto after the tsunami, a Tamil language radio station raised funds on the air to be given to the Canadian Red Cross. LTTE representatives in Toronto let the fundraisers know that their efforts to split donations between the Red Cross and their own fundraising efforts were not welcome. Given the political split within the LTTE in April 2004 between cadres loyal to LTTE leader Prabhakaran based in the North and those aligned with the breakaway faction of General Karuna in the East, as well as criticism of LTTE tactics (see note 8), such fragmentation in the diaspora is not unexpected.

8. The distinction between anti-chauvinist politics and antinationalist politics is an important one. Historical grievances held by Tamils who have experienced systemic discrimination by the Sinhala-dominated state since independence in 1948 constitute grounds for Tamil nationalism. How to achieve social justice for Tamils in Sri Lanka remains an open and deadly question. In August 2006, Kethesh Loganathan, a Tamil nationalist who opposed the Tigers' violent methods, was murdered in his yard. Exactly a year before Loganathan's death, foreign minister Lakshman Kadirgamar, who was the highest ranking Tamil in government at the time, was also killed for being a "Tamil betrayer" (Sengupta 2006). Likewise, Neelan Thiruchelvam, a constitutional lawyer and human rights advocate for Tamils in Sri Lanka, was killed by an LTTE suicide bomber in his car on his commute to work in 1999. The point here is not to normatively dismiss nationalism and the struggles to which it refers, but to consider the terms on which injustice, hate, and change are waged. As Kumari Jayawardena (1986) has argued, nationalism was an important political moment for Sri Lanka in its anti-colonial struggle against the British for independence, even if politicians used nationalism and state-building as a reason to subordinate gender equality at the time.

\section{References}

Abeysekera, Charles, and Newton Gunasinghe, eds. 1987. Facets of ethnicity in Sri Lanka. Colombo: Social Scientists' Association.

Agamben, Giorgio. 1998. Homo sacer: Sovereign power and bare life, trans. D. Heller-Roazen. Stanford, CA: Stanford University Press.

Amoore, Louise, and Marieke De Goede. 2005. Governance, risk and dataveillance in the war on terror. Crime, Law and Social Change 43:149-73.

Apps, Peter. 2006. Shelling a call to war, Tamil rebels say. The Globe and Mail 7 August.

Associated Press. 2005. Report: Sri Lankan president pushes for controversial buffer zone after tsunami scare. Colombo 29 March.

Bigo, Didier. 2002. Security and immigration: Toward a critique of the governmentality of unease. Alternatives 27:63-92.

Cassim, Nisthar. 2005. Govt. gets flexible on buffer zone rule. Daily Mirror 10 October.

Centre for Policy Alternatives. 2005. Landlessness and land rights in post-tsunami Sri Lanka. CPA report commissioned by the International Federation of the Red Cross. Colombo, 16 November.

Cheran, Rudhramoorthy. 2000. Changing formations: Tamil nationalism and national liberation in Sri Lanka and the diaspora. $\mathrm{PhD}$ diss., Department of Sociology, York University.

Citizenship and Immigration Canada. 2001. Facts and figures 2000: Immigration overview. Ottawa: Ministry of Public Works and Government Services Canada.

CIDA [Canadian International Development Agency]. 2001. Strengthening aid effectiveness. Unpublished discussion paper, February. 
2005a. CIDA announces new development partners: Developing countries where Canada can make a difference. News release, 19 April.

. $2005 \mathrm{~b}$. A role of pride and influence in the world: Development. Canada's International Policy Statement, Gatineau, QC: Her Majesty the Queen in Right of Canada.

Connelly, William. 2002. Neuropolitics: Thinking, culture, speed. Minneapolis: Minnesota University Press.

Couldrey, Marion, and Tim Morris. 2005. UN assesses tsunami response. Special issue (tsunami). Forced Migration Review 24:6-9.

Daniel, Val. 1997. Suffering nation and alienation. In Social suffering, ed. A. Kleinman, V. Das, and M. Lock, 309-58. Berkeley: University of California Press.

de Alwis, Kingsley A. 2005. The 100-metre rule-What's the logic? The Island 25 May.

de Alwis, Malathi. 1998. Moral mothers and stalwart sons. In Women and war reader, ed. Lois Ann Lorentzen and Jennifer Turpin, 254-71. New York: New York University Press.

Dias, Sunimalee. 2006. Key donors divided over post tsunami work. Daily Mirror 7 February.

The Economist. 2005. Relief but little rebuilding. The Economist 24 December.

Fernando, Santhush. 2005. Sri Lanka to strictly enforce exclusion zone. Sunday Times 24 April.

Fuglerud, Oivind. 1999. Life on the outside: The Tamil diaspora and long distance nationalism. London: Pluto Press.

Glassman, Jim. 2005. Editorial: Tsunamis and other forces of destruction. Environment and Planning D: Society and Space 23:164-70.

Glenny, Misha. 1992. The fall of Yugoslavia: The third Balkan war. London, New York: Penguin.

Gregory, Derek. 2004. The colonial present. Malden, MA: Blackwell.

Grundy-Warr, Carl, and James D. Sidaway. 2006. Political geographies of silence and erasure. Political Geography 25: 479-81.

Gunasinghe, Newton. 1987. Ethnic conflict in Sri Lanka: Perceptions and solutions. In Facets of ethnicity in Sri Lanka, 61-71. Colombo: Social Scientists Association.

Hyndman, Jennifer. 2003. Aid, conflict, and migration: The Canada-Sri Lanka connection. The Canadian Geographer 47 (3): 251-68.

2005. Migration wars: Refuge or refusal? Editorial. Geoforum 36 (1): 3-6.

-2006. Gender, space, and security in post-tsunami Sri Lanka. Presentation to the International Association of Studies in Forced Migration, Toronto, 19 June.

2007. Feminist geopolitics revisited: Body counts in Iraq. The Professional Geographer 59 (1): 35-46.

Hyndman, J., and M. de Alwis. 2004. Bodies, shrines, and roads: Violence, (im)mobility, and displacement in Sri Lanka. Gender, Place and Culture 11 (4): 535-57.

Institute for Policy Studies. 2005. Sri Lanka: State of the economy 2005. Colombo: Institute for Policy Studies, October.

Ismail, Qadri. 1995. Unmooring identity: The antimonies of elite Muslim self-representation in modern Sri Lanka. In Unmaking the nation: The politics of identity and history in modern Sri Lanka, ed. Pradeep Jeganathan and Qadri Ismail, 55-105. Colombo: Social Scientists' Association.

Jansz, Frederica. 2005. Using the tsunami to muzzle the people. Sunday Leader 20 February: 8.
Jayawardena, Kumari. 1986. Feminism and nationalism in the Third World. London: Zed Books.

. 1990. Ethnic and class conflicts in Sri Lanka: Some aspects of Sinhala Buddhist consciousness over the past 100 years. Colombo: Sanjwa Books.

Jayawardena, Kumari, and Malathi de Alwis. 1996. Introduction. In Embodied violence: Comunalising women's sexuality in South Asia, ed. Kumari Jayawardena and Malathi de Alwis, ix-xxii. New Delhi: Kali for Women.

Jeganathan, Pradeep. 2005. South paw one. In Lines, e-journal 3 (4), at www.lines-magazine.org/Art_Feb05/Pradeep.htm (last accessed 2 June 2005).

Jeganathan, Pradeep, and Qadri Ismail, eds. 1995. Unmaking the nation: The politics of identity and history in modern Sri Lanka. Colombo: Social Scientists' Association.

Jeyeraj, D. B. S. 2005. The state that failed its people. The Sunday Leader 6 February: 17.

Kangararachchi, Ramini, and Irangika Range. 2005. 65 percent of tsunami hit shun buffer zone. Daily News 2 June: 1 .

Lawson, Victoria. 2005. Natural disaster or space of vulnerability. AAG Newsletter 40 (3): 3-4.

Le Billon, Philippe, and Arno Waizenegger. 2006. Peace in the wake of disaster? Secessionist conflicts and the 2004 Indian Ocean tsunami. Working paper, Department of Geography, University of British Columbia, Vancouver.

Macrae, Joanna, and Nick Leader. 2000. Shifting sands: The search for "coherence" between political and humanitarian responses to complex emergencies. Humanitarian Policy Group Report 8, August. London: Overseas Development Institute.

Marston, Richard. 2005. Geography and the Indian Ocean tsunami. AAG Newsletter 40 (2): 1, 4.

McDowell, Christopher. 1996. A Tamil diaspora: Sri Lankan migration, settlement and politics in Switzerland. Providence, RI: Bergahn.

McEwan, Ian. 2005. Saturday. Toronto: Alfred A. Knopf (Toronto: Vintage Canada edition 2006).

Mongia, Radhika V. 1999. Race, nationality, mobility: A history of the passport. Public Culture 11:527-56.

MONLAR and ANRHR [Movement for National Land and Agricultural Reform and Alliance for Protection of National Resources and Human Rights]. 2005. Tsunami update II. In Lines, e-journal 3 (4), at www.linesmagazine.org/tsuna $\mathrm{mi} /$ MonlarJan22.htm (last accessed 2 June 2005).

Mountz, Alison. 2003. Embodied geographies of the nationstate: An ethnography of Canada's response to human smuggling. PhD diss., Department of Geography, University of British Columbia.

- 2004. Embodying the nation-state: Canada's response to human smuggling. Political Geography 23 (3): 323-45.

- Forthcoming. The transnationalization of border enforcement: Refugees, irregular migrants, and the shifting geographies of enforcement. International Migration Review.

Nah, Alice M., and Tim Bunnell. 2005. Ripples of hope: Acehnese refugees in post-tsunami Malaysia. Singapore Journal of Tropical Geography 26 (2): 249-56.

Nanthikesan, S. 2005. Editorial: Post tsunami posturing. Lines, e-journal 3 (4) at http://www.lines-magazine.org/Art_Feb05/ Editorial_Nanthi.htm (last accessed 2 June 2005).

Nesiah, Vasuki, S. Nanthikesan, and Ahilan Kadirgamar. 2005. Post-tsunami reconstruction-New challenges, new directions. In Lines, e-journal 3 (4), at http://www. 
lines-magazine.org/tsunami/linestsunamivision.htm (last accessed 2 June 2005).

Olds, Kris, James D. Sidaway, and Matthew Sparke. 2005. Editorial: White death. Environment and Planning D: Society and Space 23:475-79.

Ó Tuathail, Gearoíd. 2003. "Just out looking for a fight": American affect and the invasion of Iraq. Antipode 34:856-70.

. 2006. Geopolitical discourses: Paddy Ashdown and the tenth anniversary of the Dayton Peace Accords. Geopolitics 11:141-58.

Perera, Amantha. 2005. The buffer zone fiasco. The Sunday Leader 25 December: 16.

Perera, Jehan. 2005. NGO attack. Daily Mirror 9 May.

RADA. 2006. Coast conservation buffer zone limits relaxed. Ad in The Sunday Times 5 February: 6.

Sambandan, V. S. 2005. Tsunami and rehabilitation: The rebuilding phase. Frontline: India's National Magazine from the publishers of THE HINDU 22 (4): 12-25. February.

Seager, Joni. 2006. Editorial: Noticing gender (or not) in disasters. Geoforum 37:2-3.

Sengupta, Somini. 2006. Sri Lanka rebels critic silenced by bullet. New York Times 26 November:6.

Siriwardene, Regie, K. Indrapala, Sunil Bastian, and S. Kottegoda. 1982. School textbooks and communal relations in Sri Lanka, part 1. Colombo: Council for Communal Harmony through the Media.

Sivanandan, Ananda. 1990. Communities of resistance: Writing on Black struggles for socialism. London/New York: Verso.

Slater, David, and Morag Bell. 2002. Aid and the geopolitics of the post-colonial: Critical reflections on new labour's overseas development strategy. Development and Change 33 (3): 335-60.

Sparke, Matthew B. 2006. A neoliberal nexus: Economy, security and the biopolitics of citizenship on the border. Political Geography 25:151-80.

Spencer, Jonathan, ed. 1990. Sri Lanka: History and the roots of conflict. London/New York: Routledge.

Sriskandarajah, D. 2002. The migration-development nexus: Sri Lanka case study. Paper prepared for the Centre for Development research study: Migration-Development Links: Evidence and Policy Options, Magdalen College: Oxford, U.K.

Statistics Canada. 2001. Immigrant status and period of immigration (10A) and place of birth of respondent (260) for immigrants and non-permanent residents, for Canada, Provinces, Territories. Census Metropolitan Areas and Census Agglomerations. 2001 Census, Data Cat. No. 97F0009XCB01002.

Stokke, Kristian. 1998. Sinhalese and Tamil nationalism as post-colonial projects from "above," 1948-1983. Political Geography 17 (1): 83-113.

Swamy, M. R. N. 1996. Tigers of Lanka: From boys to guerillas, 2nd ed. Colombo: Vijitha Yapa Bookshop.

Thiruchelvam, Neelan. 1996. Sri Lanka's ethnic conflict and preventive action: The role of NGOs. In Vigilance and vengeance: NGOs preventing ethnic conflict in divided societies, ed. R. Rotberg, 147-64. Washington, DC: Brookings Institution.

Tissera, Brian. 2005. Buffer zone a hindrance-GL. The Island 19 February:7.

Uyangoda, Jayadeva. 2005. Ethnic conflict, the Sri Lankan state and the tsunami. Special issue (tsunami). Forced Migration Review 24, available on 24 August 2005 at www.fmre view.org/pdf/uyangoda.pdf.

Walters, William. 2004. Secure borders, safe haven, domopolitics. Citizenship Studies 8 (3): 237-60.

Wayland, S. 2004. Nationalist networks and transnational opportunities: The Sri Lankan Tamil diaspora. Review of International Studies 30:405-26.

\section{Primary Sources: Interviews}

Interview 9: Senior Managers, CIDA Programme Support unit, 9 February 2005.

Interview 12: Senior Managers, CIDA, Ottawa, Quebec, 12 June 2002.

Interview 13: Senior Manager, CIDA, Ottawa, Quebec, 13 June 2002.

Interview 25: Canadian High Commissioner to Sri Lanka, Colombo, 25 February 2005.

Interview 35: Senior Manager, CIDA, Ottawa, Quebec, 25 July 2005. 